\title{
Immigration and gender as differentiating elements in the motivation and strategies of Spanish secondary students
}
José Manuel Suárez ${ }^{1}$, Ana Patricia Fernández ${ }^{1}$, Ángela Zamora $^{1}$

${ }^{1}$ Departamento MIDE II (OEDIP), Facultad de Educación, UNED, Madrid

\section{España}

Correspondencia: José Manuel Suárez Riveiro. C/ Juan del Rosal, 14, 28040 Madrid. España. E-mail: jmsuarez@edu.uned.es

(C) Education \& Psychology I+D+i and Ilustre Colegio Oficial de la Psicología de Andalucía Oriental (Spain) 


\begin{abstract}
Introduction. The debate over the education of immigrant pupils relative to native Spanish students is currently a hot topic, but very little research has been undertaken in this area in Spain. The objective of this study was to detect certain possible differences in motivation and strategies between immigrant and Spanish pupils, and also between boys and girls.
\end{abstract}

Method. A sample of 436 secondary school pupils was used. The Motivated Strategies for Learning Questionnaire (MSLQ) was used as a basis, but was adapted in the shape of the elimination of the goal sub-scales (intrinsic and extrinsic), which were replaced by the Goal Orientation Scale of Skaalvik. Various Student's t-tests were carried out to determine whether or not there were statistically significant differences between the independent samples studied, concretely in respect of nationality of origin and of gender. In interpreting results, account was also taken of the effect of the size of sample. Moreover, MANOVA analyses were also used to check whether there were any interactions between the nationality of origin and gender in respect of the variables studied.

Results. In general, it was noteworthy that the main differences found were linked to the gender of pupils, much more than their nationality of origin. Hence, statistically significant differences were found in a total of twelve variables by gender and only three by nationality. Moreover, differences encountered lay mostly in the area of learning strategies rather than in academic motivation and self-motivation.

Discussion and conclusion. As a general conclusion for this study, it may be emphasized that the main differences recorded were in respect of gender, much more than with regard to the nationality of origin. More specific studies would be desirable so as to develop further this line of investigation, which is novel in a Spanish context.

Keywords: immigrants, gender, academic motivation, learning strategies, self-motivation 


\section{Resumen}

Introducción. El debate sobre la educación de estudiantes inmigrantes respecto a los estudiantes autóctonos constituye un tema actual pero sobre el cual existe muy escasa investigación en España. El objetivo del presente estudio es el de detectar algunas de las posibles diferencias en motivación y en estrategias entre estudiantes inmigrantes y españoles, así como entre hombres y mujeres.

Método. Se utilizó una muestra de 436 estudiantes de educación secundaria mediante un muestreo no probabilístico. El Motivated Strategies for Learning Questionnaire como base, pero se realizó una adaptación que consistió en eliminar las subescalas de metas (instrínsecas y extrínsecas), reemplazándolas con el Goal Orientation Scale de Skaalvik. Se realizaron varios análisis t de Student para determinar si había diferencias significativas entre las muestras independientes estudiadas, concretamente con respecto a la nacionalidad de origen y el género. Para la interpretación de resultados, también se tuvo en cuenta el efecto del tamaño de la muestra. Además, se utilizaron análisis MANOVA para comprobar si se producían interacciones entre la nacionalidad de origen y el género con respecto a las variables estudiadas.

Resultados. Se puede destacar que las principales diferencias obtenidas se han producido respecto al género; en mucha mayor medida que respecto a la nacionalidad de origen de los estudiantes. Así, se han encontrado diferencias significativas en un total de doce variables respecto al género y sólo en tres respecto a la nacionalidad de origen. Y además, dichas diferencias se sitúan principalmente en relación a las estrategias de aprendizaje, en mayor medida que en su motivación académica y que en su automotivación.

Discusión y Conclusión. Como conclusión general de este estudio, se puede destacar que las principales diferencias se obtuvieron con respecto al género, en mucha mayor medida que con respecto a la nacionalidad de origen. Sería deseable el desarrollo de estudios más específicos para desarrollar esta línea de investigación que resulta novedosa en el contexto español.

Palabras Clave: inmigrantes, género, motivación académica, estrategias de aprendizaje, automotivación. 


\section{Introducción}

The relative academic success or failure of given groups of immigrant pupils versus native Spaniards and of girls versus boys is currently a topic of debate. Thus, the results of PISA 2012 in Spain showed that Spanish pupils achieved 492 points in mathematics while students of immigrant origin scored 439 (Ministerio de Educación, Cultura y Deporte, 2014a). While girls do better at reading than boys, it is male pupils who score higher in mathematics and sciences. With regard to the first, debate centres primarily on state education, owing to the changes in foreign pupils attending state schools (Salinas \& Sandin, 2012). The figures show that the 307,151 pupils of this sort present in the academic year 2002 to 2003 had increased to 731,167 by 2014 to 2015 . Of these, $82.3 \%$ were enrolled in state schools, representing $9.04 \%$ of their total student body nationwide and coming to nearly $15 \%$ in some of Spain's autonomous regions (Ministerio de Educación, Cultura y Deporte, 2014b).

However, it is necessary to keep in mind that taking a uniform approach to any of the groups in question is a totally mistaken line to follow. Hence, treating the group of immigrant pupils as fully homogeneous, when they come from contexts as varied as Asia, South America or North Africa, is as much or more of an error as doing so with native Spanish pupils, with females or with males. Thus, immigrant pupils may, for example, be characterized by a high level of academic motivation for a number of varied reasons, such as seeing education as a tool, a means of getting a job and a higher social status than their parents', or as an outcome of the transmission of favourable values by the family. However, they can equally well by characterized by a poor level of academic motivation, for instance because in their family surroundings there are low expectations of their possibilities for academic achievement. In consequence, the study of the characteristics of immigrant pupils was approached solely on the basis of their one common characteristic, belonging to a group that had moved from another country to Spain. The intention was to undertake exploratory analyses that might later permit more specific and in-depth investigations.

Although certain patterns of motivation and learning can be recognized, they cannot be considered universal. This is because academic motivation does not reflect merely the idiosyncratic wishes of a single pupil, but rather is modulated by the predominant meanings of the cultural context in which pupils are immersed. This cultural context gives pupils access to 
complex information structures that can place a different significance on the same behaviour in different cultures. By way of an example, a behaviour as basic as eating will have different emotional and social connotations (satisfaction, celebration, importance for health and so forth), depending on the culture within which it occurs.

Learning strategies may be seen as having a more universal nature, as they are directed towards handling information or the surroundings, as a process leading to learning. Nevertheless, the best known motivational patterns in education, such, for instance, as intrinsic motivation, may have a geographical character that is strongly Western and a social character that is primarily middle-class (Morling \& Kitayama, 2008). This would be an outcome of the fact that different cultures give pupils differing information structures (Richerson \& Boyd, 2005). Consequently, the meanings of one and the same behaviour can vary in different cultures, as the intentions of that behaviour may differ. This fact may lead to immigrant pupils to behave differently with regard to their studies and moreover to want different things from them.

Academic motivation is thus seen as socialized, making possible various influences from contexts. The most relevant in the case of immigrant pupils is highly likely to be the family context. This is because this context has not just on the socialization of every individual, but in respect of immigrant pupils who have left their country of origin the main cultural influence from the place where they have their roots comes through the family. In this way, the family transmits important messages about education and about themselves.

A range of variables have been considered in the study of academic motivation. Among them, academic goals and self-efficiency have pride of place. Ames (1992b) states that a goal defines an integrated pattern of beliefs, attributions and emotions that produce intentions to behave. The goals and objectives of the immigrant population in respect of education are to a large degree determined by the characteristics of families. For instance, the rate of illiteracy among this group is higher than in the rest of the population and in many cases what they are seeking in an improved educational level for their children is no more than for them to have the minimum schooling required to find a job. In other cases, education is perceived as a means of ensuring a better future and achieving upwards social mobility for their children, as is often true of Latino families (Guzmán, Feliciano, \& Jiménez, 2011; Kasinitz, Mollenkopf, Waters, \& Holdaway, 2008). Hence, according to Kao \& Tienda (1995) the better academic results of second-generation immigrants relative to third-generation might be 
due to the fact that the former benefit from their parents' optimism about the opportunities offered by the country where they have settled.

According to a study by Elliot, Chircov, Kim, \& Sheldon (2001), cultural differences relating to the adoption of goals do not seem to be so much in the choice of learning versus performance objectives as in the selection of approach or of avoidance as a target. So, pupils from cultures in which interdependence is stressed tend to choose avoidance goals to a greater extent than those from cultures that are less concerned with collective matters. However, it would also seem that in those cases where avoidance is a target thanks to cultural influence, this goal does not exercise the negative effects that are often attributed to it. In fact, according to Eaton \& Dembo (1997) fear of failure is a positive predictor of performance in some cultures.

Pupils with an Asian or Oriental background mostly have a stronger tendency to adopt group goals, so as to achieve greater social harmony and avoid interpersonal conflicts. Approaches based on intrinsic motivation hold that when pupils perform tasks as a result of their own free choice they usually persist more and put in greater effort, as well as enjoying this work more (Deci \& Ryan, 1985). However, it has also been considered that the perspective of intrinsic motivation applies more to Western cultures, which adopt a more independent approach. In cultures characterized by greater interdependence, personal choice is not as relevant and pupils might even be more motivated to perform tasks if this work is what major figures in their surroundings, such as parents or teachers, want them to do (Morling \& Kitayama, 2008). In other words, in some cultures the desires of other people of importance may be a strong driver of motivation, more powerful even than pupils' own wishes.

Intrinsic and extrinsic motivation have not been sufficiently investigated with regard to the immigrant population. Nevertheless, running counter to the views noted above, in a study undertaken in Canada with secondary-school children, Areepattamannil \& Freeman (2008) found that the immigrant pupil group had levels significantly higher than the Canadian-born pupils in both intrinsic and extrinsic motivation.

Similarly, in a Spanish context Alonso-Tapia \& Simón (2012) also found significant differences in intrinsic motivation between Spanish and immigrant pupils, favouring the immigrants. However, no significant differences were noted between Spanish pupils and immi-500 - 
grants in respect of the various types of goal orientation investigated (approaching command, approaching performance and avoiding performance). Another variable studied in association with academic motivation is self-image as a student and one of its facets, self-efficiency. It is worth noting that different cultures may differ in the ways they approach self-image, rather than all doing it in the same fashion. A study carried out in Canada by Areepattamannil \& Freeman (2008) found that the immigrant pupil group had significantly higher levels than the Canadian-born in verbal, mathematical and academic self-image.

However, there is not just the level of self-image to be taken into account, as it can happen that different cultures may take varying approaches to conceiving the self-image through differing thoughts and feelings. The clearest distinction is to be found between certain Western cultures and others from Asia and Africa. In the former there is a tendency to see the self-image in an independent way, while in the latter it is felt to be interdependent, as a function of whether in constructing the self-image the relationship of the individual with other people is taken into account. If others are kept in mind, the self-image will be influenced by how individuals perceive themselves, but also by how they perceive themselves in relation to others and the roles they play in the group. In cultures encouraging an independent approach, personal considerations, such as achieving a high level of performance or having freedom to choose, will be more relevant than social opinions and norms, such as benefiting the group to which the individual belongs or complying with the expectations it has of that individual. Both views, independent and interdependent, might perhaps occur together in one single culture, but there would always be a tendency for one of the ways of facing up to the self-image to predominate, as also for one to be seen as more "natural" (Morling \& Kitayama, 2008).

However, besides individuals' own perceptions of themselves, it is also relevant how others perceive them. In the case of immigrant pupils the views of them held by others would seem fundamental, as they can also affect their own views of themselves. So, even if teachers may have a positive attitude towards the presence of immigrant pupils in their classrooms (on which see, for instance, Campo, Álvarez, Castro, \& Álvarez, 2005), some groups of immigrant pupils are usually seen as not very capable or hard-working, whilst others are considered highly competent and hard-working. Examples of these different labellings that generate expectations are South American and Asian pupils. 
In some cases, constant exposure of pupils to negative stereotypes may lead them to disconnect their sense of self-esteem from the academic context. This would give rise to a mechanism of down-grading anything to do with schooling, with the aim of protecting selfrespect. De-identification has been defined as a defensive uncoupling of self-esteem from actual results in a given domain so that self-respect is not dependent upon outcomes in that area (Schmader, Major, \& Gramzow, 2001). The direct consequences of this would be a lack of interest in academic matters. The stereotypes found in their surroundings are highly relevant to pupils. This is because even if they reject such images these can become internalized (Murdock, 2009).

A study carried out in Spain by Alonso-Tapia \& Simón (2012) found statistically significant differences between Spanish and immigrant pupils in various variables relating to expectations. Thus, Spanish pupils scored higher in respect of family expectations of success, of self-efficiency expectations (capability) and of expectations based on help from others, while no differences were found in expectations of self-control (effort).

Further variables to take into consideration are the interest and value of tasks. Hence, Western pupils tend to be more interested or set a higher value on a given task or subject as a function of whether it allows them to demonstrate their capability, and choose those at which they are good so as to keep their self-esteem high. In contrast, Asian and Oriental pupils do not take less interest in tasks with which they may have problems, as they do not feel that making mistakes in them necessarily damages their self-esteem, besides which this may help them progress. However, such Oriental pupils do show greater interest in tasks or subjects that permit them to build relationships at a social level or bring something to society (Morling and Kitayama, 2008). It is also of relevance whether or not pupils feel that there is interest in their academic progress on the part of those in their surroundings. In the Spanish context, Alonso-Tapia \& Simón (2012) found that Spanish children reported significantly higher levels of interest from their family in their schooling than did immigrant pupils.

\section{The aim}

From some Western viewpoints it has come to be believed that academic motivation follows a series of universal patterns. However, as put forward in this paper, it must be noted that there are important cultural differences which must not be forgotten when considering topics as crucial as academic motivation and learning by pupils. For this reason, the aim of 
this study was to locate differences in motivation and strategies between Spanish and immigrant pupils, and also between girls and boys. We expected to obtain important differences between Spanish and immigrant pupils, and also between girls and boys.

\section{Méthod}

\section{Participants}

The sample used in the study comprised 436 pupils from all round Spain using a nonprobability sample. They were distributed by course as follows: 200 and 131 in the third and fourth years of compulsory secondary education, and 73 and 32 in the first and second years of Baccalaureate. The mean age was $15.84(\mathrm{SD}=2.23)$. Half of them had a foreign nationality. The original sample of Spanish children was larger, but random selection was used to bring the group down to parity in numbers with foreign pupils. Of the total sample used, $47.6 \%$ were males and $52.4 \%$ females.

\section{Instruments}

This work took the Motivated Strategies for Learning Questionnaire (MSLQ) by Pintrich, Smith, Garcia, \& Mckeachie (1991) as a basis, but made an adaptation in the shape of the elimination of the goal sub-scales (intrinsic and extrinsic), replacing them with the Goal Orientation Scale of Skaalvik (1997). This tool has four sub-scales that provide measurement of: task orientation, which is focused on the task more than on external rewards, and in which learning and developing skills are ends in themselves; self-enhancing ego orientation, which is defined as having the goal of demonstrating abilities and doing better than others; selfdefeating ego orientation, which involves attempting to avoid appearing foolish or being judged negatively by others; and, finally, avoidance orientation, in which an attempt is made to finish academic work with the minimum possible effort. For these, a five-point Likert scale was used, running from $1=$ Never to 5 = Always.

The overall reliability of the data obtained was 0.80 , with the values for the seven subscales lying between 0.85 and 0.63 . Specifically, these were: for task orientation, 0.79 ; for self-enhancing ego orientation, 0.75 ; for self-defeating ego orientation, 0.83 ; for avoidance orientation, 0.63 ; for self-efficiency in performance, 0.85 ; for beliefs about control and selfefficiency for learning, 0.76; and for anxiety, 0.71). 
The overall reliability co-efficient (alpha co-efficient) obtained for the learning strategies scale was quite high, at 0.86 , and showed good internal consistency. In respect of most of the sub-scales the alphas obtained were good or reasonable. They were: for elaboration, 0.82; organization, 0.80; time management and effort, 0.22; seeking help, 0.59; repetition, 0.68; metacognitive self-regulation, 0.66. Here the very low figure for the time and effort management factor (only 0.22 ) is striking; so its reading should be done with the obvious precautions.

The structure emerging from factorial analysis of the data, using the principal component method and varimax rotation that gives the best fit from a theoretical point of view is one with seven factors, bringing together thirty-three items and explaining $56.34 \%$ of total variance. For the strategies portion, it was one with six factors, bringing together thirty-five items and explaining $46.88 \%$ of total variance.

\section{Procedure}

Our secondary school student sample completed the questionnaires in regular class hours. Participation was voluntary and the confidentiality of student responses was guaranteed, with data access limited to the researchers. Students were told that this was not an examination and that they should complete the questionnaires anonymously. They were further informed that there were no right or wrong answers, only statements that to a greater or lesser extent might reflect their thoughts and behaviours during learning and study.

\section{Data Analysis}

Before any analysis of difference of averages was performed, a check was made whether the variables to be used matched the criteria of normality and homoscedasticity. This was done with Kolmogorov-Smirnov and Levene tests. As the criteria established were fulfilled, parametric tests were used. Specifically, various Student's t-tests were carried out to determine whether or not there were significant differences between the independent samples studied, concretely in respect of nationality of origin and of gender.

In interpreting results, account was also taken of the effect of the size of sample, for which purpose the values of Cohen's d were used. As these were results referring to the field of educational research, it was felt that figures should be seen as of definite significance from 0.30 onwards. This is because in education there are usually smaller size effects than in other disciplines, so that values of around 0.30 are already judged as relevant (Valentine \& Cooper, 
2003). Moreover, MANOVA analyses were also used to check whether there were any interactions between the nationality of origin and gender in respect of the variables studied.

\section{Results}

The results of analyses of differences of means obtained with regard to the learning strategy variables indicate the existence of statistically significant differences in only one variable in respect of nationality of origin (Table 1), but in all the variables in respect of gender. Thus, pupils of foreign origin showed a significantly higher score in meta-cognitive selfregulation than Spanish natives, at a level that may be considered moderate. Females showed significantly higher scores than males in all the learning strategies studied, at levels that may be considered high.

Table 1. Means, Standard Deviations and Student's T-test among pupils of Spanish and of Foreign Origin and in Relation to Gender with Regard to Learning Strategies

\begin{tabular}{|c|c|c|c|c|c|c|c|c|c|}
\hline \multirow[t]{2}{*}{ Strategy } & \multirow[t]{2}{*}{$\begin{array}{l}\text { Nationality of } \\
\text { origin }\end{array}$} & \multirow[t]{2}{*}{ M } & \multirow[t]{2}{*}{ SD } & \multirow{2}{*}{\multicolumn{2}{|c|}{$\begin{array}{c}\begin{array}{c}\text { Levene test for } \\
\text { equality of vari- } \\
\text { ances }\end{array} \\
\text { F }\end{array}$}} & \multicolumn{3}{|c|}{$\begin{array}{l}\text { T-test for equality } \\
\text { of means }\end{array}$} & \multirow[t]{2}{*}{ Cohen's d } \\
\hline & & & & & & $P$ & $t$ & $p$ & \\
\hline Repetition & $\begin{array}{c}\text { Spaniards } \\
\text { Foreigners }\end{array}$ & $\begin{array}{l}3.56 \\
3.68\end{array}$ & $\begin{array}{l}.989 \\
.904\end{array}$ & \multicolumn{2}{|r|}{1.423} & .234 & -.885 & .377 & .13 \\
\hline Organization & $\begin{array}{l}\text { Spaniards } \\
\text { Foreigners }\end{array}$ & $\begin{array}{l}3.21 \\
3.28\end{array}$ & $\begin{array}{c}1.021 \\
.864\end{array}$ & \multicolumn{2}{|r|}{4.562} & .034 & -.480 & .632 & .07 \\
\hline Elaboration & $\begin{array}{l}\text { Spaniards } \\
\text { Foreigners }\end{array}$ & $\begin{array}{l}2.95 \\
3.10\end{array}$ & $\begin{array}{l}.796 \\
.745\end{array}$ & \multicolumn{2}{|r|}{.373} & .542 & -1.42 & .159 & .20 \\
\hline $\begin{array}{l}\text { Management of time and } \\
\text { effort }\end{array}$ & $\begin{array}{l}\text { Spaniards } \\
\text { Foreigners }\end{array}$ & $\begin{array}{l}3.14 \\
2.97\end{array}$ & $\begin{array}{l}.780 \\
.733\end{array}$ & \multicolumn{2}{|r|}{.784} & .377 & 1.561 & .120 & .23 \\
\hline Seeking help & $\begin{array}{l}\text { Spaniards } \\
\text { Foreigners }\end{array}$ & $\begin{array}{l}3.15 \\
3.09\end{array}$ & $\begin{array}{l}.864 \\
.852\end{array}$ & \multicolumn{2}{|r|}{.137} & .712 & .561 & .575 & .07 \\
\hline $\begin{array}{l}\text { Metacognitive self- } \\
\text { regulation }\end{array}$ & $\begin{array}{l}\text { Spaniards } \\
\text { Foreigners }\end{array}$ & $\begin{array}{l}3.23 \\
3.47\end{array}$ & $\begin{array}{l}.875 \\
.831\end{array}$ & \multicolumn{2}{|r|}{.255} & .614 & -2.02 & .045 & .28 \\
\hline \multirow[t]{2}{*}{ Strategy } & \multirow[t]{2}{*}{ Gender } & $\mathrm{M}$ & SD & $\begin{array}{r}\text { Le } \\
\text { equali }\end{array}$ & $\begin{array}{l}\text { ne test for } \\
\text { of variances }\end{array}$ & $\begin{array}{l}\text { T-test } f \\
\text { of }\end{array}$ & $\begin{array}{l}\text { for eq } \\
\text { mean }\end{array}$ & $\begin{array}{l}\text { quality } \\
\text { ns }\end{array}$ & Cohen's $d$ \\
\hline & & & & $\mathrm{F}$ & $p$ & $t$ & & $p$ & \\
\hline Repetition & $\begin{array}{c}\text { Male } \\
\text { Female }\end{array}$ & $\begin{array}{l}3.39 \\
3.85\end{array}$ & $\begin{array}{l}.972 \\
.886\end{array}$ & .459 & .499 & -3.551 & & .000 & .49 \\
\hline Organization & $\begin{array}{l}\text { Male } \\
\text { Female }\end{array}$ & $\begin{array}{l}3.02 \\
3.45\end{array}$ & $\begin{array}{l}.924 \\
.940\end{array}$ & .009 & .925 & -3.257 & & .001 & .46 \\
\hline Elaboration & $\begin{array}{l}\text { Male } \\
\text { Female }\end{array}$ & $\begin{array}{l}2.86 \\
3.15\end{array}$ & $\begin{array}{l}.767 \\
.763\end{array}$ & .068 & .795 & -2.670 & & .008 & .38 \\
\hline $\begin{array}{l}\text { Management of time and } \\
\text { effort }\end{array}$ & $\begin{array}{l}\text { Male } \\
\text { Female }\end{array}$ & $\begin{array}{l}2.95 \\
3.19\end{array}$ & $\begin{array}{l}.695 \\
.811\end{array}$ & 1.959 & .163 & -2.245 & & .026 & .32 \\
\hline Seeking help & $\begin{array}{l}\text { Male } \\
\text { Female }\end{array}$ & $\begin{array}{l}2.98 \\
3.28\end{array}$ & $\begin{array}{l}.876 \\
.795\end{array}$ & .440 & .508 & -2.553 & & .011 & .36 \\
\hline $\begin{array}{l}\text { Metacognitive sel- } \\
\text { fregulation }\end{array}$ & $\begin{array}{c}\text { Male } \\
\text { Female }\end{array}$ & $\begin{array}{l}3.18 \\
3.50\end{array}$ & $\begin{array}{l}.883 \\
.818\end{array}$ & 1.018 & .314 & -2.722 & & .007 & .38 \\
\hline
\end{tabular}


In respect of motivational variables, the results point to the existence of statistically significant differences in just one variable regarding nationality of origin (Table 2) and in two of the variables studied as regards gender. Thus, pupils of Spanish origin had a significantly greater score for anxiety under examination conditions than foreign pupils, at a level that may be considered as between moderate and high. Females also had significantly higher scores than males for anxiety in examination situations, whilst males had significantly higher levels than females in respect of the goal of avoiding work, with levels that can be seen as between moderate and high.

Table 2. Means, Standard Deviations and Student's T-test between Pupils of Spanish and Foreign Origin and in Relation to Gender with respect of Motivational Variables

\begin{tabular}{|c|c|c|c|c|c|c|c|c|}
\hline \multirow[t]{2}{*}{ Motivational variable } & \multirow[t]{2}{*}{$\begin{array}{l}\text { Nationality } \\
\text { of origin }\end{array}$} & \multirow[t]{2}{*}{ M } & \multirow[t]{2}{*}{ SD } & \multicolumn{2}{|c|}{$\begin{array}{l}\text { Levene test for } \\
\text { equality of vari- } \\
\text { ances }\end{array}$} & \multicolumn{2}{|c|}{$\begin{array}{l}\text { T-test for } \\
\text { equality of } \\
\text { means }\end{array}$} & \multirow[t]{2}{*}{$\begin{array}{c}\text { Cohen's } \\
d\end{array}$} \\
\hline & & & & $\mathrm{F}$ & $p$ & $t$ & $p$ & \\
\hline Task orientation & $\begin{array}{l}\text { Spaniards } \\
\text { Foreigners }\end{array}$ & $\begin{array}{l}3.97 \\
3.90\end{array}$ & $\begin{array}{l}.815 \\
.826\end{array}$ & .801 & .372 & .579 & .563 & .13 \\
\hline Self-defeating ego orientation & $\begin{array}{l}\text { Spaniards } \\
\text { Foreigners }\end{array}$ & $\begin{array}{l}2.81 \\
2.55\end{array}$ & $\begin{array}{l}1.146 \\
1.056\end{array}$ & .294 & .588 & 1.740 & .083 & .24 \\
\hline Self-enhancing ego orientation & $\begin{array}{l}\text { Spaniards } \\
\text { Foreigners }\end{array}$ & $\begin{array}{l}2.78 \\
2.90\end{array}$ & $\begin{array}{c}1.015 \\
.980\end{array}$ & 1.277 & .260 & -.915 & .361 & .12 \\
\hline Avoidance orientation & $\begin{array}{l}\text { Spaniards } \\
\text { Foreigners }\end{array}$ & $\begin{array}{l}2.86 \\
2.79\end{array}$ & $\begin{array}{l}.953 \\
.874\end{array}$ & .245 & .621 & .609 & .543 & .08 \\
\hline $\begin{array}{l}\text { Beliefs about control and self- } \\
\text { efficiency for learning }\end{array}$ & $\begin{array}{l}\text { Spaniards } \\
\text { Foreigners }\end{array}$ & $\begin{array}{l}3.54 \\
3.64\end{array}$ & $\begin{array}{l}.823 \\
.862\end{array}$ & 1.514 & .220 & -.847 & .398 & .12 \\
\hline Self-efficiency in performance & $\begin{array}{l}\text { Spaniards } \\
\text { Foreigners }\end{array}$ & $\begin{array}{l}3.28 \\
3.20\end{array}$ & $\begin{array}{c}.979 \\
1.093\end{array}$ & 2.710 & .101 & .612 & .541 & .08 \\
\hline $\begin{array}{l}\text { Anxiety under examination condi- } \\
\text { tions }\end{array}$ & $\begin{array}{l}\text { Spaniards } \\
\text { Foreigners }\end{array}$ & $\begin{array}{l}3.36 \\
3.07\end{array}$ & $\begin{array}{l}.921 \\
.936\end{array}$ & .028 & .867 & 2.295 & .023 & .31 \\
\hline Motivacional variable & Gender & M & SD & $\begin{array}{r}\text { Levene } \\
\text { equality } \\
\text { anc }\end{array}$ & $\begin{array}{l}\text { for } \\
\text { vari- }\end{array}$ & $\begin{array}{r}\text { T-tes } \\
\text { equali } \\
\text { mea }\end{array}$ & $\begin{array}{l}\text { t for } \\
\text { ty of } \\
\text { ans }\end{array}$ & $\begin{array}{c}\text { Cohen's } \\
d\end{array}$ \\
\hline & & & & $\mathrm{F}$ & $p$ & $t$ & $p$ & \\
\hline Task orientation & $\begin{array}{c}\text { Male } \\
\text { Female }\end{array}$ & $\begin{array}{l}3.82 \\
4.03\end{array}$ & $\begin{array}{l}.819 \\
.809\end{array}$ & .109 & .741 & -1.81 & .072 & .26 \\
\hline Self-enhancing ego orientation & $\begin{array}{l}\text { Male } \\
\text { Female }\end{array}$ & $\begin{array}{l}2.91 \\
2.76\end{array}$ & $\begin{array}{c}1.003 \\
.988\end{array}$ & .036 & .850 & 1.101 & .272 & .15 \\
\hline Self-defeating ego orientation & $\begin{array}{l}\text { Male } \\
\text { Female }\end{array}$ & $\begin{array}{l}2.61 \\
2.68\end{array}$ & $\begin{array}{l}1.016 \\
1.156\end{array}$ & 1.758 & .186 & -.444 & 657 & .06 \\
\hline Avoidance orientation & $\begin{array}{l}\text { Male } \\
\text { Female }\end{array}$ & $\begin{array}{l}2.97 \\
2.69\end{array}$ & $\begin{array}{l}.931 \\
.877\end{array}$ & .110 & .740 & 2.319 & .021 & .31 \\
\hline $\begin{array}{l}\text { Beliefs about control and self- } \\
\text { efficiency for learning }\end{array}$ & $\begin{array}{c}\text { Male } \\
\text { Female }\end{array}$ & $\begin{array}{l}3.59 \\
3.60\end{array}$ & $\begin{array}{l}.806 \\
.880\end{array}$ & .747 & .388 & -.033 & .974 & .01 \\
\hline Self-efficiency in performance & $\begin{array}{l}\text { Male } \\
\text { Female }\end{array}$ & $\begin{array}{l}3.13 \\
3.32\end{array}$ & $\begin{array}{c}.982 \\
1.091\end{array}$ & 1.078 & .300 & -1.28 & .204 & .18 \\
\hline $\begin{array}{l}\text { Anxiety under examination condi- } \\
\text { tions }\end{array}$ & $\begin{array}{l}\text { Male } \\
\text { Female }\end{array}$ & $\begin{array}{l}3.00 \\
3.36\end{array}$ & $\begin{array}{l}.957 \\
.892\end{array}$ & 1.685 & .196 & -2.80 & .006 & .39 \\
\hline
\end{tabular}


The only interaction between nationality of origin and gender that was found was with regard to the variable self-enhancing ego orientation (Wilks's lambda $\lambda=0.959 ; F(4,175)=$ $4,210, p<0.041 ; \eta 2 \mathrm{p}=0.021)$. Thus, although no statistically significant differences in the goal of self-enhancement were found either between nationalities of origin or between the genders, such statistically significant differences were found between Spanish $(\mathrm{M}=2.51, \mathrm{SD}$ $=1.006)$ and foreign $(\mathrm{M}=2.94, \mathrm{SD}=0.945)$ girls $(t=2.37, p=0.020, d=.44)$, as also between female $(\mathrm{M}=2.51, \mathrm{SD}=0.964)$ and male $(\mathrm{M}=2.99, \mathrm{SD}=1.006)$ Spaniards $(t=2.40, p$ $=.018, d=.49)$ at levels that can be considered high (Figure 1).

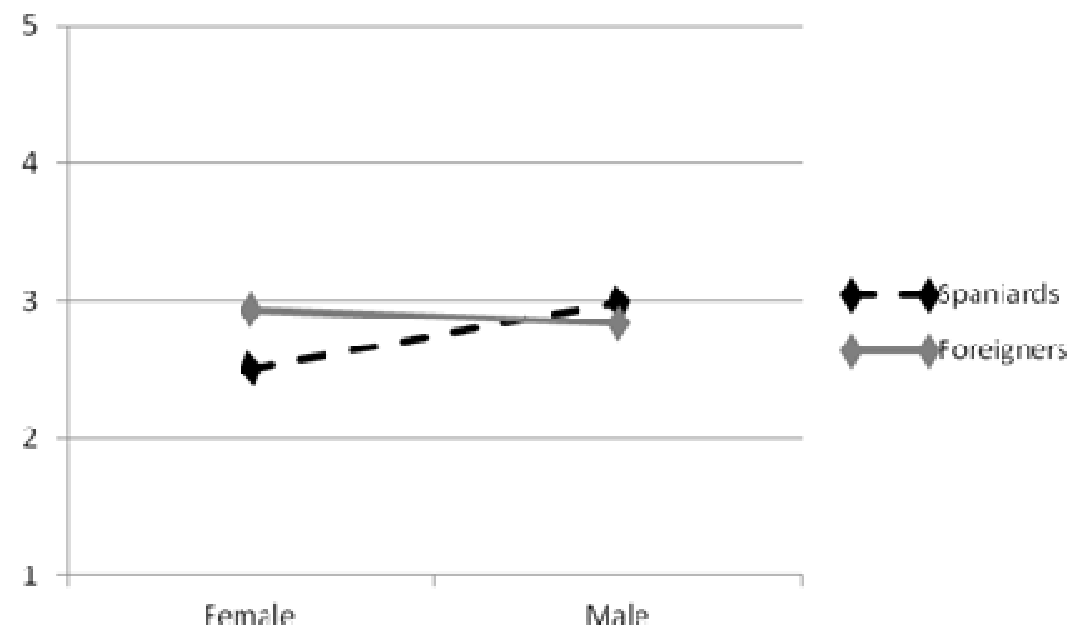

Figure 1. Averages (means) in the the variable self-enhancing ego orientation as a function of nationality of origin and of gender of the pupils.

For their part, the results of analyses of differences in means obtained for variables relating to self-motivation strategies within the expectations component showed statistically significant differences in one variable, the strategy of praising others, in respect both of nationality of origin and of gender (Table 3) and in the strategy of disparaging others solely in respect of gender. Thus, pupils of foreign origin and males both showed a significantly higher score for praising others, at a high level. Moreover, males also had significantly greater scores than females in the strategy of disparaging others, at a very high level. 
Table 3. Means, standard deviations and Student's T-test among Pupils of Spanish and Foreign Origin and among Pupils of Both Genders with Regard to Motivational Strategies in the Expectations Component

\begin{tabular}{|c|c|c|c|c|c|c|c|c|}
\hline \multirow[t]{2}{*}{ Strategy } & \multirow[t]{2}{*}{$\begin{array}{l}\text { Nationality of } \\
\text { origin }\end{array}$} & \multirow[t]{2}{*}{$\mathrm{M}$} & \multirow[t]{2}{*}{ SD } & \multicolumn{2}{|c|}{$\begin{array}{l}\text { Levene test for } \\
\text { equality of vari- } \\
\text { ances }\end{array}$} & \multicolumn{2}{|c|}{$\begin{array}{l}\text { T-test for } \\
\text { equality of } \\
\text { means }\end{array}$} & \multirow[t]{2}{*}{ Cohen's $d$} \\
\hline & & & & $\mathrm{F}$ & $p$ & $t$ & $p$ & \\
\hline Praising others & Spaniards & 1.82 & .749 & 10.308 & 002 & -2.790 & .006 & .43 \\
\hline $\begin{array}{l}\text { Generating positive expecta- } \\
\text { tions }\end{array}$ & Spaniards & 3.31 & $\begin{array}{l}.000 \\
.783 \\
756\end{array}$ & .000 & .996 & -.963 & .337 & .14 \\
\hline Disparaging others & $\begin{array}{l}\text { Spaniards } \\
\text { Foreigners }\end{array}$ & $\begin{array}{l}2.49 \\
2.67\end{array}$ & $\begin{array}{l}1.052 \\
1.048\end{array}$ & .027 & .869 & -1.096 & .275 & .18 \\
\hline Defensive pessimism & $\begin{array}{l}\text { Spaniards } \\
\text { Foreigners }\end{array}$ & $\begin{array}{l}3.03 \\
3.01\end{array}$ & $\begin{array}{l}.828 \\
.768\end{array}$ & .264 & .608 & .164 & .870 & .03 \\
\hline Self-handicapping & $\begin{array}{l}\text { Spaniards } \\
\text { Foreigners }\end{array}$ & $\begin{array}{l}2.38 \\
2.64\end{array}$ & $\begin{array}{l}.833 \\
.932\end{array}$ & 1.580 & .210 & -1.955 & .052 & .30 \\
\hline $\begin{array}{l}\text { Generating external attribu- } \\
\text { tions }\end{array}$ & $\begin{array}{l}\text { Spaniards } \\
\text { Foreigners }\end{array}$ & $\begin{array}{l}3.06 \\
3.07\end{array}$ & $\begin{array}{l}.883 \\
.903\end{array}$ & .043 & .835 & -.024 & .981 & .00 \\
\hline Self-affirmation & $\begin{array}{l}\text { Spaniards } \\
\text { Foreigners }\end{array}$ & $\begin{array}{l}2.55 \\
2.79\end{array}$ & $\begin{array}{l}.970 \\
.875\end{array}$ & .246 & .621 & -1.730 & .085 & .26 \\
\hline \multirow[t]{2}{*}{ Strategy } & \multirow[t]{2}{*}{ Gender } & \multirow[t]{2}{*}{ M } & \multirow[t]{2}{*}{ SD } & \multicolumn{2}{|c|}{$\begin{array}{l}\text { Levene test for } \\
\text { equality of vari- } \\
\text { ances }\end{array}$} & \multicolumn{2}{|c|}{$\begin{array}{l}\text { T-test for } \\
\text { equality of } \\
\text { means }\end{array}$} & Cohen's $d$ \\
\hline & & & & $\mathrm{F}$ & $p$ & $t$ & $p$ & \\
\hline Praising others & $\begin{array}{l}\text { Male } \\
\text { Female }\end{array}$ & $\begin{array}{l}2.20 \\
1.84\end{array}$ & $\begin{array}{l}.965 \\
.829\end{array}$ & 2.644 & .106 & 2.559 & .011 & .40 \\
\hline $\begin{array}{l}\text { Generating positive expecta- } \\
\text { tions }\end{array}$ & $\begin{array}{l}\text { Male } \\
\text { Female }\end{array}$ & $\begin{array}{l}3.39 \\
3.39\end{array}$ & $\begin{array}{l}.821 \\
.708\end{array}$ & 1.809 & .180 & -.019 & .985 & .00 \\
\hline Disparaging others & $\begin{array}{l}\text { Male } \\
\text { Female }\end{array}$ & $\begin{array}{l}2.86 \\
2.31\end{array}$ & $\begin{array}{r}.996 \\
1.052\end{array}$ & .529 & .468 & 3.426 & .001 & .54 \\
\hline Defensive pessimism & $\begin{array}{l}\text { Male } \\
\text { Female }\end{array}$ & $\begin{array}{l}3.02 \\
3.00\end{array}$ & $\begin{array}{l}.812 \\
.789\end{array}$ & .003 & .953 & .188 & .851 & .03 \\
\hline Self-handicapping & $\begin{array}{l}\text { Male } \\
\text { Female }\end{array}$ & $\begin{array}{l}2.63 \\
2.42\end{array}$ & $\begin{array}{l}.813 \\
.973\end{array}$ & 2.220 & .138 & 1.514 & .132 & .23 \\
\hline $\begin{array}{l}\text { Generating external attribu- } \\
\text { tions }\end{array}$ & $\begin{array}{l}\text { Male } \\
\text { Female }\end{array}$ & $\begin{array}{l}3.10 \\
3.03\end{array}$ & $\begin{array}{l}.852 \\
.941\end{array}$ & 1.078 & .301 & .558 & .577 & .08 \\
\hline Self-affirmation & $\begin{array}{l}\text { Male } \\
\text { Female }\end{array}$ & $\begin{array}{l}2.79 \\
2.59\end{array}$ & $\begin{array}{l}.927 \\
.916\end{array}$ & .074 & .786 & 1.404 & .162 & .22 \\
\hline
\end{tabular}

In their case, the variables for self-motivation strategies within the value component did not show statistically significant differences in any of their variables (Table 4). However, taking into account Cohen's $d$, it might be considered that there was a moderate difference between the genders in generation of the avoidance orientation, this being greater for males. 
Table 4. Means, Standard Deviations and Student's T-test among Pupils of Spanish and Foreign Origin and among Pupils of the Two Genders with Regard to Motivational Strategies in the Value Component

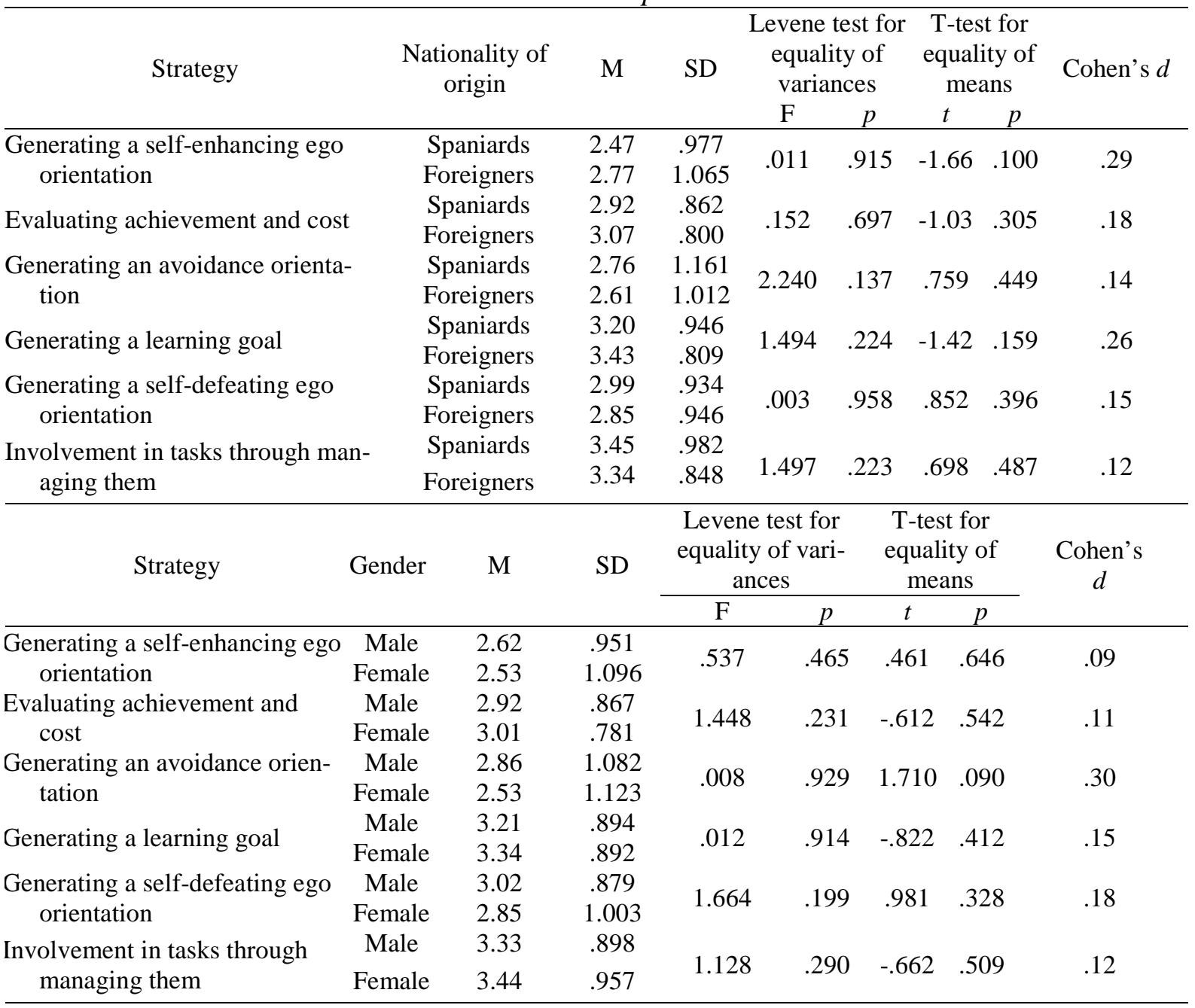

Finally, the variables self-motivation strategies within the affect component (Table 5) do not point to any statistically significant differences with regard to nationality of origin. However, they do show such differences in respect of gender in the strategies of selfreinforcement and social valuation, with very high and high levels respectively, in both instances in favour of females. In fact, the difference between boys and girls in the strategy of self-reinforcement is the one with the greatest size of effect in this study. 
Table 5. Means, standard deviations and Student's T-test among Pupils of Spanish and Foreign Origin and among pupils of the Two Genders with Regard to Motivational Strategies in the Affect Component

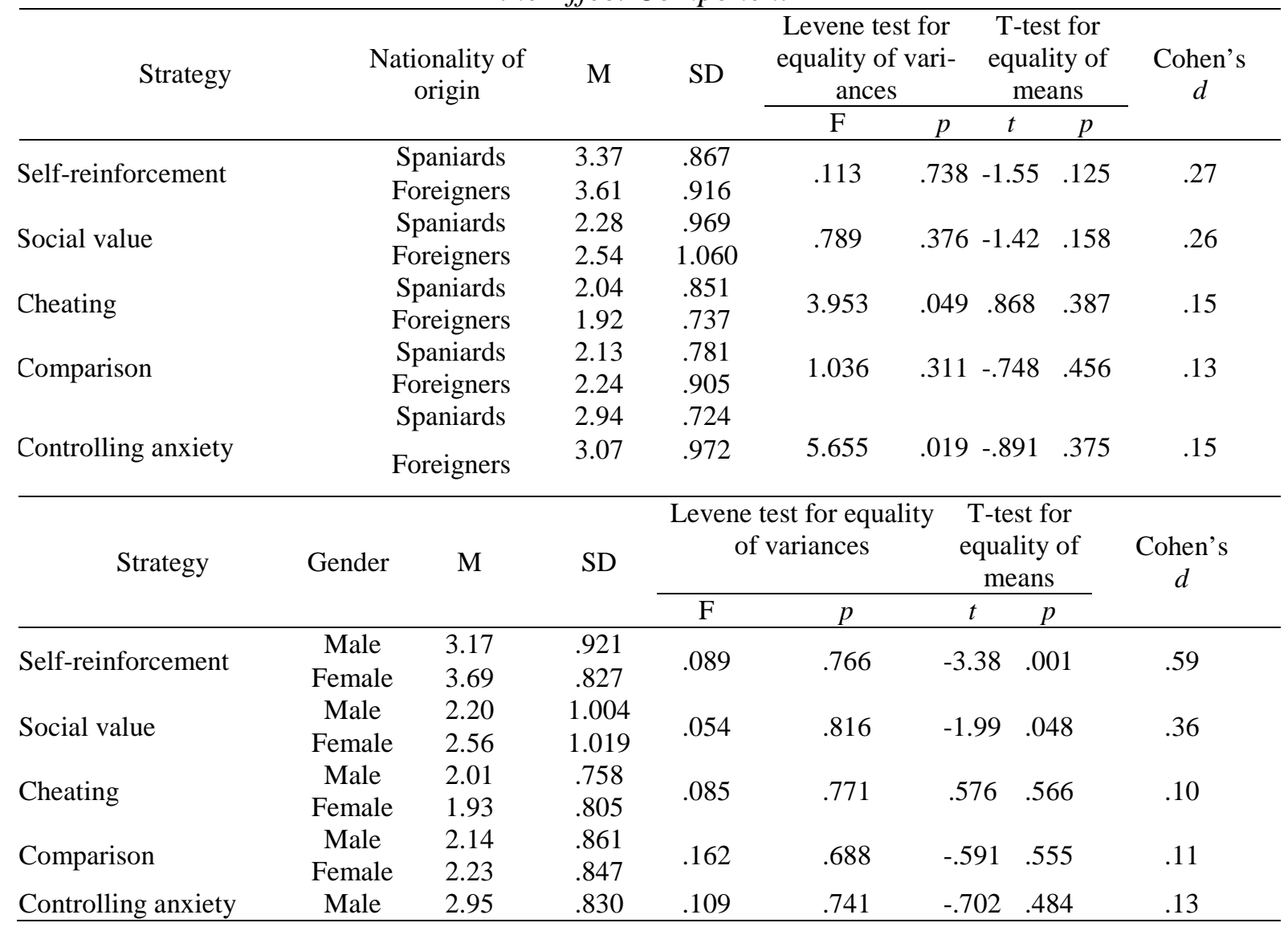

\section{Discussion and conclusions}

As a general conclusion for this study, it may be emphasized that the main differences recorded were in respect of gender, much more than with regard to the nationality of origin of pupils. Thus, statistically significant differences were found in a total of twelve variables with regard to gender and only three in respect of the nationality de origin. Moreover, these latter differences were principally in relation to learning strategies.

The differences detected in relation to nationality of origin favoured non-Spanish pupils in the use both of metacognitive self-regulation strategies and of praising others, as also to a lesser level in respect of anxiety in examination situations. Hence, it can be stated that in view of the number of variables studied the differences found were few. Thus, no differences were noted in variables which a priori might have been assumed to show them, as an outcome of differing socialization, especially in the family context, through experiences, self- 
perceptions or the importance and instrumental function assigned to education. So, as was also noted by Alonso-Tapia \& Simón (2012), no differences were seen in respect of the adoption of learning goals versus performance goals or with regard to having goals of approaching versus avoiding performance. It was in this latter dichotomy that it would have been assumed that differences were most likely to be found, according to the views put forward by Elliot et al. (2001).

With regard to beliefs about control and self-efficiency, no differences were found either. However, they had been noted by Alonso-Tapia \& Simón (2012) relative to expectations of self-efficiency. Similarly, despite the variety of self-motivation strategies investigated, differences were found only in the strategy of praising others, employed to a greater degree by pupils of foreign origin. That is to say, pupils who were of foreign nationality reported a more extensive use of the strategy of highlighting the qualities of their classmates in an attempt to protect their image, thus attributing bad results not to a lack of ability or effort but to other causes, representing their fellow-students (or at least some of them) as academically very capable.

It should be pointed out that the work reported here approached the study of the motivational characteristics and the strategies of pupils as a function of their nationality of origin. Hence, it took as its starting point a shared characteristic, which was whether or not individuals belonged to a group which had come from some other country to Spain. As a consequence, in view of the heterogeneity of pupils whose nationality of origin was not Spanish, it may be accepted that what the study achieved was not so much a characterization of this group of foreign origin as the determination of differential features of the population of Spanish origin. These, as has been seen above, were very few.

The differences detected in relation to gender favoured females very clearly with regard to using all the learning strategies. This was true to a lesser degree in respect of academic motivation (lower levels of anxiety under examination conditions and of the workavoidance orientation) and of a total of four self-motivation strategies (praising others, disparaging others, self-reinforcement and social value). These results are consistent with those of other studies, such as Cerezo \& Casanova (2004), with regard to learning strategies. These authors did not, however, find differences in support strategies like those which were noted here. Similarly, they found no differences in motivational variables like learning goals or 
academic self-image. Moreover, unlike the results reported here, Fernández (2010) did find differences in task orientation, with self-deprecation of the ego commoner among females and self-enhancement of the ego among males.

Only one interaction was detected between the variables gender and nationality of origin, this being in the self-enhancing ego orientation variable. Spanish girls reported a significantly lower level than foreign girls and Spanish boys in this respect. In other words, Spanish females' statements suggested that they strove less hard to demonstrate their capabilities and perform better than others relative to Spanish males and foreign females. This is consistent with previous results relating to Spanish boys (Broc, 2006; Cerezo \& Casanova, 2004; Fernández, 2010).

This study of the motivation of immigrant pupils was undertaken solely from the perspective of one shared characteristic, belonging to the group of people who have come from some other country to Spain. Thus, other, more specific, analyses would be desirable so as to develop further this line of investigation, which is novel in a Spanish context. Hence, for example, it would be of interest for future studies to take into consideration the more general region of the world (for instance, East or West) or the specific country of origin, or even the background (for example, rural or urban) or socio-economic level. This could be rounded out by a study of how different cultures may have varying ways of understanding motivational variables as an outcome of different thought-patterns and feelings.

\section{References}

Alonso-Tapia, J. \& Simón, C. (2012). Differences between immigrant and national students in motivational variables and classroom-motivational-climate perception. The Spanish $\begin{array}{llll}\text { Journal of } & \text { Psychology, }\end{array}$ http://dx.doi.org/10.5209/rev_SJOP.2012.v15.n1.37284

Ames, C. (1992). Classrooms: Goals, structures and student motivation. Journal of Educational Psychology, 84(3), 261-271. http://dx.doi.org/10.1037/0022-0663.84.3.261

Areepattamannil, S. \& Freeman, J. G. (2008). Academic achievement, academic selfconcept, and academic motivation of inmigrant adolescents in the greater Toronto area secondary schools. Journal of Advanced Academics, 19, 700-743. http://dx.doi.org/10.4219/jaa-2008-831 
Broc, M. A. (2006). Motivación y rendimiento académico en alumnos de Educación Secundaria Obligatoria y Bachillerato LOGSE [Motivation and academic performance in secondary students]. Revista de Educación, 340, 379-414. http://dx.doi.org/10.4438/1988-592X-0034-8082-RE

Campo, M. A., Álvarez, M., Castro, P. \& Álvarez, E. (2005). La situación de los alumnos extranjeros vista por los maestros de primaria [The situation of foreign pupils as seen by primary-school teachers]. Aula Abierta, 86, 205-218.

Cerezo, M. T. \& Casanova, P. F. (2004). Diferencias de género en la motivación académica de los alumnos de Educación Secundaria Obligatoria [Differences by sex in the academic motivation of pupils undertaking obligatory secondary education]. Electronic Journal of Research in Educational Psychology, 2(1), 97-112.

Deci, E.L. \& Ryan, R.M. (1985). Intrinsic motivation and self-determination in human behavior. New York: Plenum Press.

Eaton, M. \& Dembo, M. (1997). Differences in the motivational beliefs of Asian Americans and non-Asian students. Journal of Educational Psychology, 89, 433-440. http://dx.doi.org/10.1037/0022-0663.89.3.433

Elliot, A.J., Chirkov, V., Kim, Y., \& Sheldon, K.M. (2001). A cross-cultural analysis of avoidance (relative to approach) personal goals. Psychological Science, 12(6), 505510. http://dx.doi.org/10.1111/1467-9280.00393

Fernández, A. P. (2010). Motivación académica en estudiantes de Secundaria y su relación con la utilización de estrategias de automotivación [Academic motivation in secondary students and its relationship with the use of selfmotivation strategies] (Unpublished doctoral thesis). UNED, Madrid.

Guzmán, R., Feliciano, L. A. \& Jiménez, A. B. (2011). Dificultades de aprendizaje del alumnado inmigrante hispano: la perspectiva de los coordinadores de Programas de Educación Intercultural [Learning difficulties of Hispanic immigrant pupils: the perspective of co-ordinators of intercultural education programmes]. Revista de Educación, 355, 547-570. http://dx.doi.org/10-44381/1988-592X-RE-2010-355-036

Kao, G. \& Tienda, M. (1995). Optimism and achievement: The educational performance of inmigrant youth. Social Science Quarterly, 76, 1-19.

Kasinitz, P., Mollenkopf, J., Waters M. \& Holdaway, J. (2008). Inheriting the city. The Children of Immigrants Come of Age. Cambridge: Harvard University Press. http://dx.doi.org/10.1111/j.1468-2427.2012.01216_5.x 
Ministerio de Educación, Cultura y Deporte (2014a). Datos y cifras. Curso escolar 2014/15 [Data and figures for the academic year 2014 to 2015]. Madrid: Secretaría General Técnica del MEC. Retrieved from http://www.mecd.gob.es/servicios-al-ciudadano-

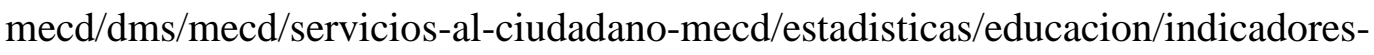
publicaciones-sintesis/datos-cifras/Datosycifras1415.pdf

Ministerio de Educación, Cultura y Deporte (2014b). PISA 2012. Informe Español [PISA 2012. Report on Spain]. Madrid: Instituto Nacional de Evaluación Educativa. Retrieved from http://www.mecd.gob.es/dctm/inee/internacional/pisa2012/boletin21 pisa2012.pdf?doc umentId=0901e $72 \mathrm{~b} 8178650 \mathrm{~b}$

Morling, B. \& Kitayama, S. (2008). Culture and motivation. In J. Y. Shah \& W. L. Gardner (Ed.), Handbook of motivation science (pp. 417-432). New York: Guilford Press.

Murdock, T. B. (2009). Achievement motivation in racial and ethnic context. In K. R. Wentzel \& A. Wigfield (Eds.), Handbook of Motivation at School (pp. 433-462). New York: Routledge.

Pintrich, P.R., Smith, D.A., Garcia, T. \& Mckeachie, W.J. (1991). A manual for the use of the Motivated Strategies for Learning Questionnaire (M.S.L.Q.)Ann Arbor, MI: NCRIPTAL, The University of Michigan.

Richerson, P. J. \& Boyd, R. (2005). Not by genes alone. Chicago: University of Chicago Press. http://dx.doi.org/10.7208/chicago/9780226712130.001.0001

Salinas, J. \& Santín, D. (2012). Selección escolar y efectos de la inmigración sobre los resultados académicos españoles en PISA 2006 [School Choice and the Influence of Inmigration on Spanish Educational Achievements in the 2006 PISA]. Revista de Educación, 358, 382-405. http://dx.doi.org/10.4438/1998-592X-RE-2011-358-083

Schmader, T., Major, B., \& Gramzow, R. H. (2001). Coping with ethnic stereotypes in the academic domain: perceived injustice and psychological disengagement. Journal of Social Issues, 57(1), 93-111. http://dx.doi.org/10.1111/0022-4537.00203

Skaalvik, E.M. (1997). Self-enhancing and self-defeating ego orientation: Relations with task and avoidance orientation, achievement, self-perceptions, and anxiety. Journal of Educational Psychology, 89(1), 71-81. http://dx.doi.org/10.1037/0022-0663.89.1.71

Stevenson, H. W. \& Stigler, J. W. (1992). The learning gap: Why our schools are failing and what we can learn from Japanese and Chinese education. New York: Summit Books. Valentine, J. \& Cooper, H. (2003). Effect Size Substantive Interpretation Guidelines: Issues in the Interpretation of Effect Sizes. Washington, D.C.: What Works Clearing House. 